\title{
Determinants of Household Savings in India: An Empirical Analysis Using ARDL Approach
}

\author{
Amaresh Samantaraya and Suresh Kumar Patra \\ Department of Economics, Pondicherry University, Kalapet, Pondicherry 605014, India \\ Correspondence should be addressed to Amaresh Samantaraya; amaresheco@gmail.com
}

Received 19 April 2014; Revised 30 June 2014; Accepted 3 July 2014; Published 16 July 2014

Academic Editor: Sajal Lahiri

Copyright (c) 2014 A. Samantaraya and S. K. Patra. This is an open access article distributed under the Creative Commons Attribution License, which permits unrestricted use, distribution, and reproduction in any medium, provided the original work is properly cited.

\begin{abstract}
Indian economy witnessed significant transformations in the postreform period both in terms of change in policy paradigm adopting greater market orientation and overall macroeconomic performance with development of a broad-based financial market and increasing global integration. Guided by the fact that domestic savings play a critical role in augmenting capital accumulation and contributing to achieve and sustain high economic growth, an attempt to review and reassess the role of various factors influencing domestic savings under the changed environment is quite relevant for sustaining the growth momentum. In this backdrop, the present study empirically analyzed the role of various determinants of household savings in India with the latest available data. It employed ARDL approach for this purpose due to its suitability for estimating an equation with a mix of stationary and nonstationary variables of order $I(1)$ and address potential endogeneity problems. The estimated results revealed that GDP, dependency ratio, interest rate, and inflation have statistically significant influence on household savings in India, both in the long run and short run. As regards policy implications, we suggest that ensuring price stability and avoiding any disruption to the growth process will be useful for augmenting savings and sustaining the savings-growth spiral in India.
\end{abstract}

\section{Introduction}

The role of savings and investment in achieving and maintaining high economic growth is extensively laid out in the theories of economic growth. Harrod-Domar growth theory highlighted how economic growth depends on the rate of saving or investment and the incremental capital-output ratio in the economy. The neoclassical growth theory due to Solow [1] assigned a critical role to saving rate for facilitating a higher growth in per capita capital and per capita income in the transition to the steady state and also implied that a high saving rate facilitates achieving a higher level of steady state per capita capital and income. Subsequently, fully endogenous growth models suggest that increases in saving rate and in the size of population increase the longterm growth rate. Consistent with theoretical predictions, empirical evidences also strongly support close interlinkages between savings and economic growth in a cross-country perspective. It is observed that economies witnessing rapid economic growth such as China, India, Indonesia, Malaysia,
Singapore, South Korea, and Thailand are also characterized by high saving rates. Similarly, many countries in subSaharan Africa and Latin America typically save at a low rate and experience slow economic growth. In this backdrop, analysis of determinants of savings in an economy is very relevant to formulate appropriate policy initiatives fostering higher savings and thus higher economic growth.

Athukorala and Sen [2] have highlighted the relevance for country specific study to assess the role of determinants of domestic savings as the cross-country studies suffer from the restrictive "homogeneity" assumption, while in reality there are considerable variation across the countries in regard to various structural features and institutional factors that have a direct bearing on the impact of economic factors on the saving process. Deaton [3] and Srinivasan [4] also warn against cross-country studies in this area due to vast differences in nature and quality of data across the countries. Guided by the above, we focus on India to assess the role of various determinants of savings. 


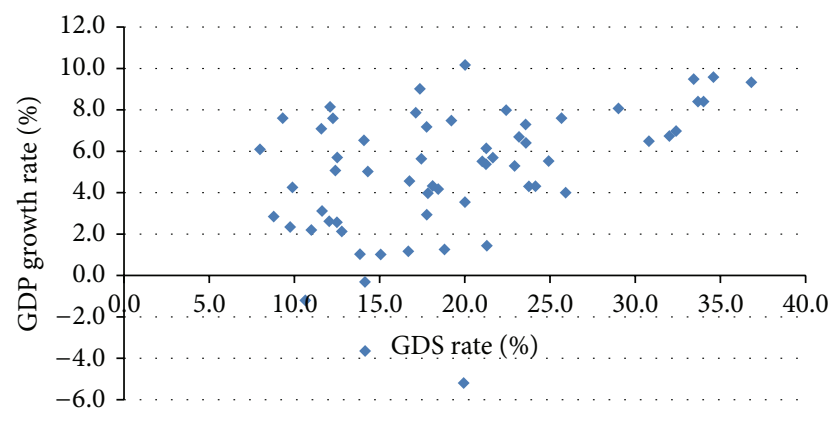

FIGURE 1: Economic growth and saving rate in India.

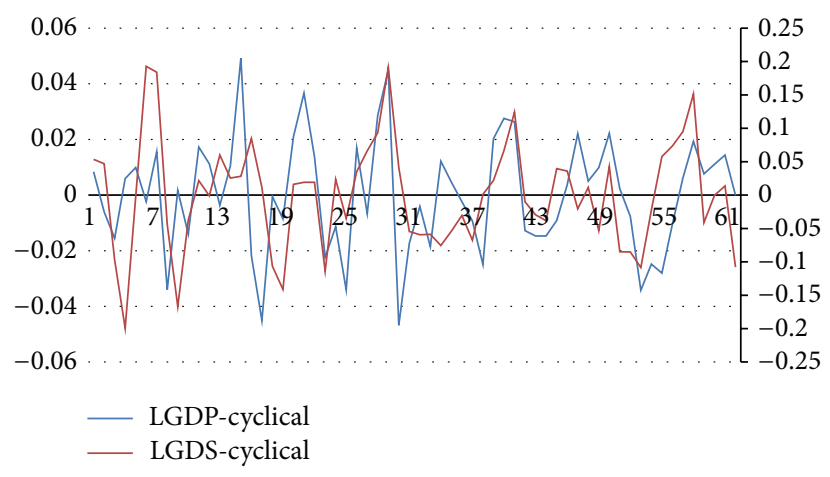

FIgure 2: Procyclicality of savings in India.

In the Indian context, it was observed that the average economic growth during the first three decades since independence was around 3.5 percent. During this period, the average gross domestic savings as a percentage of GDP (GDS rate) was 13.5 percent. Average economic growth accelerated to 5.6 percent during the 1980 s, when average GDS rate accentuated to 18.6 percent. The average economic growth during the postreform period (1992-93 to 2011-12) further increased to 7 percent. During this period, the average GDS rate also rose to 27.6 percent. Particularly, with average economic growth leaping to the higher growth trajectory of 8.5 percent during 2003-12, average GDS rate also concomitantly soared to 33.0 percent.

Figures 1 and 2 support the close association between savings and economic growth in India as discussed above. The scatter plot in Figure 1 exhibits the positive relation between real GDP growth and saving rate (GDS as a percentage of GDP). Figure 2 portrays the strong procyclicality of savings, where cyclical components of GDP and domestic savings were obtained by detrending the respective series using Hodrick-Prescott (HP) filter. Both GDP and GDS (real savings series (GDS) was obtained from the nominal series by using GDP deflator) were taken in real terms.

Guided by the strong interlinkages between savings and real activity as discussed above, and particularly given the importance of savings for facilitating high economic growth, a quite bit of the literature is available in Indian context undertaking empirical analysis on determinants of savings (Krishnamurthy and Saibaba [5], K. W. Ketkar and
S. L. Ketkar [6], Mühleisen [7], Mahambare and Balasubramanyam [8], Athukorala [9], Athukorala and Sen [2], etc.). The methodology applied by the above studies reflected gradual advancement in econometric techniques. For example, Krishnamurthy and Saibaba [5] used standard OLS analysis, while K. W. Ketkar and S. L. Ketkar [6] applied 2SLS procedure recognizing the endogeneity issues. The rest of the studies as cited above used popular time series techniques. Data coverage by most of the above studies was confined largely to the prereform period, while the later ones also included data for the 1990s. In general, these studies found economic growth, per capita income, inflation, terms of trade between industry and agriculture, trade openness, interest rate, bank branch expansion, and so forth to be significant in influencing the behavior of savings in India.

It may be noted that the postreform period in India witnessed impressive macroeconomic performance in terms of sustaining high economic growth with stable prices, integration of the Indian economy with the rest of the world, and significant improvement in savings and investment in the economy. Average economic growth accelerated to 6.9 percent during the postreform period (1992-2013) as compared to around 4.0 percent during the prereform period (19511991). Average saving rate nearly doubled to 27.8 percent from 14.9 percent during the comparable period. The ratio of foreign trade to GDP increased nearly threefold from around 15 percent in early 1990s to close to 44 percent in recent years. The structure of the economy got transformed with larger space for the market and private sector in the real economic activity, overwhelming dominance of services sector in overall GDP at the expense of agriculture and industry, and there has been a significant broadening and deepening of the financial sector. Particularly, India's average economic growth was phenomenally high at around 8.5 percent during 2003-11 varying within a range of 6.7-9.6 percent. The GDS-GDP ratio was around 33.3 percent during this period as compared around 23.0 percent during the 1990s. No comprehensive study has been carried out yet, to the best of our knowledge, to examine the dynamics in the determination of household savings including data of the high savings and growth phase of 2000s in the Indian context.

In this backdrop, the present study attempts to empirically review the role of key determinants of household savings in India using advanced econometric techniques. It may be noted that household savings continue with a dominant share of 70 to 80 percent in overall domestic savings (domestic savings consist of three main components such as household savings, private corporate savings, and public savings) in India, and behavioural theories suggesting various determinants of saving behavior of individuals can be suitably applied for this segment of domestic savings. The present study improves upon the previous studies in Indian context under the following accounts. Firstly, it uses the latest available data including the entire postreform period until 2011-12. Secondly, on methodological aspect, a common criticism of the previous studies in Indian context is regarding use of combination of stationary and nonstationary variables as determinants of savings in their empirical exercises without applying appropriate econometric tools. The present study 
employed Autoregressive Distributed Lag (ARDL) model for empirical estimations which is suitable to handle presence of both stationary and nonstationary variables. Moreover, in analysis of the determinants of savings, the behavioral models include several explanatory variables which are likely to be endogenous. For example, GDP which is considered to be a significant determinant of domestic savings is also influenced by the latter. As noted by Pesaran and Shin [10], ARDL framework facilitates addressing such potential endogeneity problem. Also it is suitable despite presence of residual serial correlation problems, which are likely to be encountered in such empirical exercises.

In the backdrop of substantial jump in domestic savings in India in the last decade, and the economy moving to a higher growth trajectory during 2003-11, the present study will unravel new dynamics in the determination of household savings in India. The findings are believed to have important policy implications aiding appropriate policy to boost domestic savings in India and consequently sustaining high economic growth.

The rest of the present paper is set out as below. Section 2 outlines the analytical framework, while Section 3 explains the issues related to data and methodology pertaining to the empirical exercise undertaken in the study. Empirical results assessing the role of various determinants of household savings in India are discussed in Section 4. Finally, Section 5 concludes with policy implications.

\section{Analytical Framework}

The analytical framework for assessing the role of various determinants of domestic saving in India is mainly based on life cycle hypothesis of saving (LCH) propounded by Modigliani and Brumberg [11] and Modigliani and Ando [12]. In the present study, the econometric model used for our empirical analysis is derived from $\mathrm{LCH}$, which is also augmented by certain improvements and extensions taking into account recent developments in consumption theory and structural aspects prevailing in a developing country like India.

The $\mathrm{LCH}$ assumes that a representative individual maximizes her utility from life-time consumption, and savings are residuals reflecting differences between individual income and consumption. Following Modigliani [13], we may conceive an individual beginning with negative savings at a young age, accumulating savings during working age, and finally returning to dissaving as she retires. The $\mathrm{LCH}$ also implies that consumption smoothing leads to a humpedshape age path of wealth holding. The saving function derived from the life-cycle model of Modigliani and Brumberg [11] is as follows:

$$
s=y-c=\frac{L-t}{L_{t}} y-\frac{(N-t)}{L_{t}} y^{e}-\frac{1}{L_{t}} a,
$$

where

$s$ is savings of an individual,

$y$ is current income of the individual, $c$ is current individual consumption,

$L$ is lifespan of economic significance,

$t$ is age of the individual,

$L_{t}$ is remaining lifespan at age $t$,

$N$ is earning span of the individual,

$y^{e}$ is expected income of the individual,

$a$ is initial assets.

Thus, from (1), current savings of an individual are a linear and homogeneous function of current income, expected average income, and initial assets, with coefficients depending on the demographic profile of the individual. In the empirical literature on the analysis of determinants of saving, (1) is extended from individual perspective to the saving function for entire economy by aggregating the saving behavior of each of the individuals in the economy.

As regards the specification of dependent variable, several empirical studies take it as the ratio of saving to income. But this approach suffers from the limitation of implicitly imposing the "income homogeneity assumption;" that is, ceteris paribus saving is proportional to income. In reality, saving and income may not move in the same proportion and hence the arbitrary imposition of income homogeneity assumption may mislead coefficient estimates (Athukorala [9]). Therefore, the present study specifies an unrestricted equation in which the dependent variable has been taken in level form and the real GDP in level appears as one of the explanatory variables.

Among other determinants, wealth (WTH) is expected to raise consumption level through the wealth effects and, thus, expected to have a negative impact on savings. The predicted link between saving and demographic factors becomes complicated in the LCH model. Dependents in both the young and the retired categories are expected to have negative savings, while the working age people are expected to save. Thus, the coefficient of "age dependency" (DEP) can be expected to be negative. On the contrary, having a higher number of dependents in a family also compels the households to save more for the future from the current earnings for consumption smoothening and overall welfare enhancement of the household. Thus, a high "age dependency" can also augment savings, if net effect is high.

Further, following the literature, the above saving function can be augmented guided by the following. According to McKinnon [14] and Shaw [15], high real interest rate promotes both financial and total saving in the economy. Raising present price of consumption relative to the future price, through substitution effect, higher interest rates provide an incentive to increase saving. However, higher interest income raises the permanent income of net lenders and, thus, tend to increase their consumption and decrease savings through the income effect. Thus, higher interest rates can raise overall savings, only if the substitution effect is stronger than the income effect and, hence, the expected sign of real interest rate on savings is theoretically ambiguous. 
Inflation may influence savings through its impact on real wealth. Higher inflation depresses the value of real wealth and through the wealth effect negatively affects consumption and thus enhances savings. Consumer's response to unanticipated changes in inflation can also result in involuntary saving (Deaton [16]). However, there can be a portfolio adjustment with a switch from financial assets to real assets during an inflationary situation.

Fiscal policy in terms of variation in fiscal deficit and personal taxes is expected to significantly influence the saving behavior. According to Barro [17], under Ricardian equivalence, higher government expenditure financed by government borrowing may result in higher saving because of anticipation of a future increase in taxes by the public. Increase in personal income tax may discourage saving since it reduces the disposable income of the people.

Furthermore, for a developing country like India, factors related to the structure of the economy in terms of share of the agriculture sector in total GDP and external terms to trade are popularly considered as relevant factors for influencing household savings. Significant decline in agriculture's share in overall GDP was considered as an important cause of the increase in saving in India after 1970s as discussed in Rakshit [18], Krishnamurthy and Saibaba [5], and Mühleisen [7]. The relationship between savings and terms of trade traditionally rested on the Harberger-Laursen-Metzler hypothesis, which states that a reduction in the price of domestically produced goods relative to that of foreign goods reduces savings. The sign of the coefficient of terms of trade mainly depends on whether its movements are perceived to be permanent or temporary (Frankel and Razin [19]).

Based on the above discussion, to assess the role of various factors influencing household saving behavior in India, the following model is constructed:

$$
\begin{gathered}
\mathrm{HSAV}=f(\operatorname{GDP}(+), \operatorname{WTH}(-), \operatorname{DEP}(+), \operatorname{INT}(+,-), \\
\operatorname{INF}(+,-), \operatorname{GFD}(+), \operatorname{INCT}(-), \\
\operatorname{AGRGDP}(-), \operatorname{NTOT}(+,-)),
\end{gathered}
$$

where

HSAV is real household savings,

GDP is real gross domestic product,

WTH is wealth,

DEP is dependency ratio,

INT is real interest rate,

INF is inflation,

GFD is gross fiscal deficit as percentage of GDP,

INCT is personal income tax as percentage of GDP,

AGRGDP is share of agriculture as percentage of GDP,

NTOT is net barter terms of trade.
The above model is used for the empirical exercise of assessing the role of various determinants of household savings in India in the following sections.

\section{Data and Methodology}

The present study employed autoregressive distributed lag (ARDL) model or bound testing approach (Pesaran et al. [20]) to assess the role of various determinants of household savings in India. As discussed in the previous section, we considered real GDP, age dependency ratio, interest rate, inflation, GFD-GDP ratio, tax to GDP ratio, share of agriculture in total GDP, and external terms of trade as key determinants of household savings. We considered ARDL model to be suitable for our empirical exercise because of the following reasons. Firstly, the set of variables used in our empirical exercise is likely to be of a mix of $I(0)$ and $I$ (1) variables. Secondly, this approach is more suitable for the small and finite sample data period (Pesaran et al. [20]). Thirdly, given the nature of interrelation between savings, GDP, and interest rate, which are included in our model, the ARDL model is suitable to address possible endogeneity issue, as indicated earlier. As noted by Pesaran and Shin [10], "appropriate modification of the orders of the ARDL model is sufficient to simultaneously correct the residual serial correlation and the problem of endogenous regressors."

Before undertaking estimation of the ARDL model, a necessary prior exercise is to apply bound test for establishing the long-run relationship between the variables included in the model. The error correction representation of the ARDL models is as follows:

$$
\begin{aligned}
\Delta \mathrm{HSAV}= & \lambda_{0}+\lambda_{1} \mathrm{HSAV}_{t-1}+\lambda_{2} \mathrm{GDP}_{t-1}+\lambda_{3} \mathrm{WTH}_{t-1} \\
& +\lambda_{4} \mathrm{DEP}_{t-1}+\lambda_{5} \mathrm{INT}_{t-1}+\lambda_{6} \mathrm{INF}_{t-1} \\
& +\lambda_{7} \mathrm{GFD}_{t-1}+\lambda_{8} \mathrm{INCT}_{t-1}+\lambda_{9} \mathrm{AGRGDP}_{t-1} \\
& +\lambda_{10} \mathrm{NTOT}_{t-1}+\sum_{i=1}^{g} \beta_{i} \Delta \mathrm{HSAV}_{t-i} \\
& +\sum_{j=0}^{h} \gamma_{j} \Delta \mathrm{GDP}_{t-j}+\sum_{k=0}^{s} \delta_{k} \Delta \mathrm{WTH}_{t-k} \\
& +\sum_{l=0}^{t} \Omega_{l} \Delta \mathrm{DEP}_{t-l}+\sum_{m=0}^{u} \theta_{m} \Delta \mathrm{INT}_{t-m} \\
& +\sum_{n=0}^{v} \sigma_{n} \Delta \mathrm{INF}_{t-n}+\sum_{o=0}^{w} \phi_{o} \Delta \mathrm{GFD}_{t-o} \\
& +\sum_{p=0}^{x} \Psi_{p} \Delta \mathrm{INCT}_{t-p}+\sum_{q=0}^{y} \mu_{q} \Delta \mathrm{AGRGDP}_{t-q} \\
& +\sum_{r=0}^{z} \vartheta_{r} \Delta \mathrm{NTOT}_{t-r}+\varepsilon_{t} .
\end{aligned}
$$

The Wald test ( $F$-statistics) derived from the above forms a critical part of ARDL procedure, which is helpful to assess 
the existence of long run relationship among the variables included in the model. The null and alternative hypotheses for the Wald test are as follows:

$$
\begin{gathered}
\mathrm{H}_{0}: \lambda_{1}=\lambda_{2}=\lambda_{3}=\lambda_{4}=\lambda_{5}=\lambda_{6}=\lambda_{7}=\lambda_{8}=\lambda_{9}=\lambda_{10}=0 \\
\mathrm{H}_{\mathrm{a}}: \lambda_{1} \neq \lambda_{2} \neq \lambda_{3} \neq \lambda_{4} \neq \lambda_{5} \neq \lambda_{6} \neq \lambda_{7} \neq \lambda_{8} \neq \lambda_{9} \neq \lambda_{10} \neq 0 .
\end{gathered}
$$

The computed F-test can be compared with the critical values provided by Pesaran et al. [20] and Narayan [21] for the hypothesis testing. According to them, the lower bound critical values assumed that the explanatory variables are integrated of order one. Therefore, if the computed $F$-statistic is less than the lower bound value, the null is not rejected. On the contrary, if the computed $F$-statistics is greater than the upper bound value, it implies existence of long-run relationship among the variables. Finally, if the computed $F$ statistics lies between the lower bound and upper bound, long run association between the variables becomes inconclusive.

On establishing the long-run relationship, one can proceed to estimate the ARDL model, first to estimate the long run coefficient from the equation, as given below:

$$
\begin{aligned}
\mathrm{HSAV}= & \lambda_{0}+\lambda_{1} \mathrm{HSAV}_{t-1}+\lambda_{2} \mathrm{GDP}_{t-1}+\lambda_{3} \mathrm{WTH}_{t-1} \\
& +\lambda_{4} \mathrm{DEP}_{t-1}+\lambda_{5} \mathrm{INT}_{t-1}+\lambda_{6} \mathrm{INF}_{t-1} \\
& +\lambda_{7} \mathrm{GFD}_{t-1}+\lambda_{8} \mathrm{INCT}_{t-1}+\lambda_{9} \mathrm{AGRGDP}_{t-1} \\
& +\lambda_{10} \mathrm{NTOT}_{t-1}+v_{t} .
\end{aligned}
$$

Finally, the short-run dynamic parameters may be obtained by estimating the VEC model as given below:

$$
\begin{aligned}
\Delta \mathrm{HSAV}= & \sum_{i=1}^{g} \beta_{i} \Delta \mathrm{HSAV}_{t-i}+\sum_{j=0}^{h} \gamma_{j} \Delta \mathrm{GDP}_{t-j} \\
& +\sum_{k=0}^{s} \delta_{k} \Delta \mathrm{WTH}_{t-k}+\sum_{l=0}^{t} \Omega_{l} \Delta \mathrm{DEP}_{t-l} \\
& +\sum_{m=0}^{u} \theta_{m} \Delta \mathrm{INT}_{t-m}+\sum_{n=0}^{v} \sigma_{n} \Delta \mathrm{INF}_{t-n} \\
& +\sum_{o=0}^{w} \phi_{o} \Delta \mathrm{GFD}_{t-o}+\sum_{p=0}^{x} \Psi_{p} \Delta \mathrm{INCT}_{t-p} \\
& +\sum_{q=0}^{y} \mu_{q} \Delta \mathrm{AGRGDP}_{t-q}+\sum_{r=0}^{z} \vartheta_{r} \Delta \mathrm{NTOT}_{t-r} \\
& +\eta \mathrm{ECT}_{t-1}+\varepsilon_{t},
\end{aligned}
$$

where $\beta, \gamma, \delta, \Omega, \theta, \sigma, \phi, \Psi, \mu$, and $\vartheta$ are the short-run dynamic coefficients and $\eta$ is the coefficient of speed of adjustment which is expected to have negative sign.

As regards data, $\mathrm{HSAV}_{t}$ is obtained by logarithmic transformation of real household savings in India, which in turn was obtained from nominal household savings by using GDP deflator. $\mathrm{GDP}_{t}$ is also used in logarithmic transformed form of GDP at factor cost at constant prices $(2004-05=100)$. In the literature, broad money stock has been used as a proxy for wealth in India. However, we believe that in the postreform period with development of a broad-based financial market in India there has been considerable accumulation of wealth in the equity and other forms. To reflect this, we attempted to construct a wealth index combining information derived both from movement of broad money stock (M3) and market capitalization in India. Given the strong interrelations between the two, this index (WTH) was constructed by employing principal component analysis (PCA) using both broad money stock (M3) and market capitalization as percentage of GDP. Principal component analysis (PCA) is a multivariate procedure which transforms a number of highly correlated variables into a smaller number of uncorrelated variables called principal components (PCs). To assess the factorability of the data, Bartlett's test of sphericity and the Kaiser-Meyer-Oklin (KMO) measure of sampling adequacy test have been also performed and these tests conform that the PCA is appropriate. Age dependency ratio (DEP) is the calculated as the percentage of population below 15 and above 64 years of age of the total working age population (15 to 64 years) in India. Interest rates are many and choosing one of them to represent real interest rate involves an element of judgment. Nevertheless, in the postreform period various interest rate in India are found to be aligned and moved together. The bank deposits rate with 1-3 years maturity adjusted for inflation is used as a proxy for real interest rate (INT) in the present study. Percentage change in the wholesale price index (WPI) is used as a measure of inflation (INF).

Other variables are a bit straight forward. GFD is calculated as gross fiscal deficit as percentage of GDP, INCT is simply personal income tax collected as percentage of GDP, and AGRGDP is percentage share of agriculture GDP to total GDP in India. Finally, NTOT is the unit value of India's exports expressed as percentage of unit value of its imports. Data required for compilation of all variables used in the present study except DEP are collected from the Handbook of Statistics on Indian Economy, 2012-13 published by the Reserve Bank of India. Data on DEP are obtained from World Development Indicators (WDI) database of the World Bank.

\section{Empirical Results and Discussion}

The empirical analysis in the present study began with assessing the stationarity conditions of the variables used in our study by applying augmented Dickey-Fuller (ADF) unit root test. The results are reported in Table 1.

It may be observed from Table 1 that our variables are a mix of stationary and nonstationary variables of order "1." Hence, the ARDL model proposed by Pesaran et al. [20] is the most suitable for estimating (2).

Applying Wald test, the $F$-statistics was calculated to be "4.97" with a lag order " 2 ." The lag order was chosen using Akaike information criterion (AIC) and Schwarz Bayesian criterion (SBC). Comparing the estimated value with the upper bound critical values of Pesaran et al. [20] and Narayan [21], the hull hypothesis of "no cointegration" is 
TABLE 1: Results of unit root test.

\begin{tabular}{lccc}
\hline Variables & Level & First difference & Inference \\
\hline HSAV & -2.79 & $-7.98^{*}$ & $I(1)$ \\
GDP & -1.34 & $-5.92^{*}$ & $I(1)$ \\
WTH & -1.82 & $-10.67^{*}$ & $I(1)$ \\
DEP & $-3.14^{*}$ & - & $I(0)$ \\
INT & $-4.39^{*}$ & - & $I(0)$ \\
INF & $-4.59^{*}$ & - & $I(0)$ \\
GFD & -2.51 & $-6.79^{*}$ & $I(1)$ \\
INCT & -1.60 & $-6.50^{*}$ & $I(1)$ \\
AGRGDP & -2.98 & $-8.05^{*}$ & $I(1)$ \\
NTOT & $-4.36^{*}$ & - & $I(0)$ \\
\hline
\end{tabular}

Note: “*” denotes significance at 1 percent level.

rejected in favour of the alternative at 5 percent level of significance (it may be noted that conventional cointegration test like Johansen-Juselius procedure looks for the existence of maximum number of cointegrating vectors, while testing for cointegration of more than two variables. Subsequently, it undertakes appropriate analysis to choose the vector among them confirming to the theoretical expectations and estimates the vector with appropriate dependent variable. However, this procedure requires all the variables under consideration to be integrated of the same order. Improving upon this limitation, ARDL model developed by Pesaran and Shin $[10,20]$ is capable of testing the long run cointegrating relation in presence of a mix of $I(0)$ and $I(1)$ variables and also takes care of the endogeneity issue). Thus, the bound test established the long run stable relationship of the variables in (2), which is developed to assess the role of various determinants of household savings in India.

On confirmation of the long run relationship, ARDL estimations were undertaken and the estimated long-run coefficients are provided as follows:

$$
\begin{aligned}
\operatorname{HSAV}_{t}( & t \text {-value }) \\
= & -34.10^{*}(-2.75)+2.56^{*} \mathrm{GDP}_{t}(2.83) \\
& -0.04 \mathrm{WTH}_{t}(-0.54)+0.22^{*} \mathrm{DEP}_{t}(3.06) \\
& -0.07^{*} \operatorname{INT}_{t}(-3.35)-0.07^{*} \mathrm{INF}_{t}(-3.23) \\
& -0.01 \mathrm{GFD}_{t}(-0.29)+0.16 \mathrm{INCT}_{t}(1.03) \\
& +0.03 \mathrm{AGRGDP}_{t}(0.99)-0.0004 \mathrm{NTOT}_{t}(-0.27) \\
& +0.10^{*} \operatorname{Trend}(2.35) .
\end{aligned}
$$

The above results reveal that variables like income, age dependency, interest rate and inflation have significant impact on household savings in the long-run. The coefficients of the above variables are statistically significant at 1 per cent level (as indicated with "**) and their respective signs are as per the theoretical expectations.

It may be interpreted that in the long run, one percentage increase in GDP leads to 2.56 percent increase in household savings, while one percentage increase in age dependency, raises household savings by close to one-fifth percentage point. Similarly, one percentage increase in interest rate and inflation reduces household savings by 0.07 percent each.

Interestingly, in the long run we could not find falling share of agriculture in total GDP to have statistically significant influence on household savings in India.

To assess the determinants of household saving in the short run, the estimated results of the VECM related to our ARDL model are presented as follows:

$$
\begin{aligned}
& \Delta \mathrm{HSAV}_{t}(t \text {-value }) \\
&=-19.96^{*}(-2.79)+1.50^{*} \Delta \mathrm{GDP}_{t}(2.67) \\
&-0.02 \Delta \mathrm{WTH}_{t}(-0.54)+0.13^{*} \Delta \mathrm{DEP}_{t}(3.01) \\
&-0.04^{*} \Delta \mathrm{INT}_{t}(-3.77)-0.04^{*} \Delta \mathrm{INF}_{t}(-4.14) \\
&-0.004 \Delta \mathrm{GFD}_{t}(-0.29)+0.09 \Delta \mathrm{INCT}_{t}(0.99) \\
&+0.02 \Delta \mathrm{AGRGDP}_{t}(1.08)+0.0002 \Delta \mathrm{NTOT}_{t}(0.26) \\
&+0.06^{* *} \Delta \operatorname{Trend}(2.34)-0.59^{*} \mathrm{ECM}_{t-1}(4.07)
\end{aligned}
$$

It may be observed from the estimated results that the same variables namely, income, age dependency, interest rate and inflation which were found to be statistically significant as determinants of household savings in India in the long run are also statistically significant in the short run. However, the magnitudes of short run coefficients are smaller as compared to their long run counter parts.

We also conducted various diagnostic checks to assess the robustness of above estimated results using ARDL model. The LM test for autocorrelation $\left(\chi^{2}\right.$ statistics $\left.=1.48\right)$ rejected the null of no autocorrelation, while that for testing heteroscedasticity $\left(\chi^{2}\right.$ statistics $\left.=2.47\right)$ could not reject the assumption of homoscedasticity. The LM test also could not reject the normality assumption $\left(\chi^{2}\right.$ statistics $\left.=0.12\right)$, and Ramsay's RESET test $(F$-statistics $=3.23)$ could not reject the fitted model. To assess the stability of the estimated regression coefficients, cumulative sum (CUSUM) and cumulative sum of squares (CUSUM SQ) of recursive residuals were also computed and are plotted in Figures 3 and 4, respectively, along with critical bounds at 5 percent significance level. From the figures, the stability of the regression coefficients is established.

\section{Summary and Conclusions}

Given the critical role of higher savings for achieving and sustaining higher economic growth, understanding the behavior of savings and its various determinants have been an interesting area of empirical research. In India, various empirical studies were carried out in the past using a variety of econometric methods. As regards the empirical analysis, the present study is an improvement as compared to the previous studies in India in this area by using ARDL framework which is capable of incorporating a mix of stationary and 


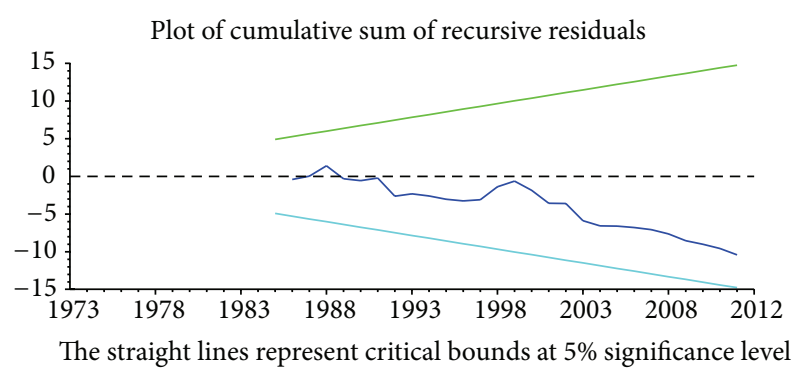

FIgURE 3: Results of CUSUM test.

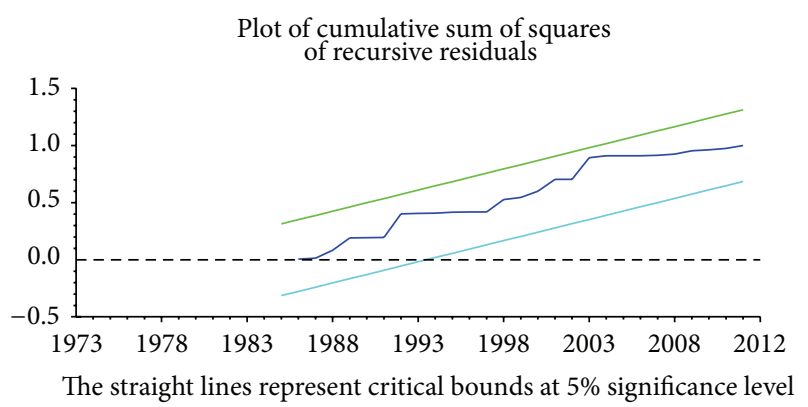

FIGURE 4: Results of CUSUM-SQ test.

nonstationary variables for the regression analysis. Moreover, it is also suitable to take care of endogeneity and serial correlation problem, which are encountered, in general, in this type of analysis. Using ARDL framework, the present study analyzed the determinants of household saving in India from the period 1971-72 to the period 2011-12. Given that during 2003-11 the economy moved up to a higher growth trajectory of around 8.5 percent and savings-GDP ratio increased by 10 percentage points, there was an imperative need to reassess the role of various determinants of households' savings in India which is the prime component of domestic saving in India.

In the backdrop of the current economic slowdown in India following a period of sustained higher growth during 2003-11, juxtaposed with the observation of a close association between household savings and economic growth in India, the present study attempts to empirically analyze the role of various determinants of savings in India. A better understanding on the role of various determinants of savings will engender suitable policy action to promote domestic savings so as to revive and sustain a high growth trajectory for India which is critical for improving the standard of living of a sizeable population in India who live under impoverished conditions.

The estimated results of the ARDL model established the long run stability in the association between the variables used in our model using bound tests, and various diagnostic tests supported robustness of estimated results.

As regards the determinants of household savings, the variables like GDP, age dependency, interest rate, and inflation were found to be statistically significant to influence household savings, both in the long run and short run. The empirical results revealed that GDP and age dependency have favorable effect on household saving, while high inflation and real interest rates exert negative impact. The negative effects of real interest rate on household savings reveal stronger income effect over the substitution effect.

Our present study has important policy implication for monetary policy. Given that inflation was found to have negative impact on household savings, ensuring price stability and low inflation will be conducive to augment household savings and thus sustain higher economic growth. Furthermore, given the strong influence of GDP on household savings and the spiral interlinkages between household savings and economic growth, any disruption to the economic growth process will seriously damage its very sustainability through income-savings nexus and severely aggravate the economic slowdown.

\section{Conflict of Interests}

The authors declare that there is no conflict of interests regarding the publication of this paper.

\section{References}

[1] R. M. Solow, "A contribution to the theory of economic growth," Quarterly Journal of Economics, vol. 70, no. 1, pp. 65-94, 1956.

[2] P. Athukorala and K. Sen, "The determinants of private saving in India," World Development, vol. 32, no. 3, pp. 491-503, 2004.

[3] A. Deaton, "Saving in developing countries, theory and review," in Proceedings of the World Bank Annual Conference on Development Economics, pp. 61-108, 1989.

[4] T. N. Srinivasan, "Data base for development analysis Data base for development analysis: an overview," Journal of Development Economics, vol. 44, no. 1, pp. 3-27, 1994.

[5] K. Krishnamurthy and P. Saibaba, "Determinants of saving rate in India," Indian Economic Review, vol. 16, no. 4, pp. 225-249, 1988.

[6] K. W. Ketkar and S. L. Ketkar, "Bank nationalization, financial savings, and economic development: a case study of India," Journal of Developing Areas, vol. 27, no. 1, pp. 69-83, 1992.

[7] M. Mühleisen, "Improving India’s Saving Performance," WP 97/4, International Monetary Fund, Washington, DC, USA, 1997.

[8] V. Mahambare and V. M. Balasubramanyam, "Liberalisation and savings in developing countries: the case of India," Working Paper 4, Lancaster University Management School, Lancaster, UK, 2000.

[9] P. Athukorala, "Interest rates, saving and investment: evidence from India," Oxford Development Studies, vol. 26, no. 2, pp. 153169, 1998.

[10] M. H. Pesaran and Y. Shin, "An autoregressive distributed lag modeling approach to cointegration analysis," in Proceedings of the Econometrics and Economic Theory in the 20th Century: The Ragnar Frisch Centennial Symposium, S. Strom, Ed., Cambridge University Press, New York, NY, USA, 1999.

[11] F. Modigliani and R. Brumberg, Utility Analysis and Consumption Function: An Interpretation of Cross Section Data, vol. 6 of The Collected Papers of Franco Modigliani, MIT Press, Boston, Mass, USA, 2005. 
[12] F. Modigliani and A. Ando, "The "life cycle" hypothesis of saving: aggregate implications and tests," The American Economic Review, vol. 53, no. 1, pp. 55-84, 1963.

[13] F. Modigliani, "Life cycle, individual thrift, and the wealth of nations," The American Economic Review, vol. 76, no. 3, pp. 297313, 1986.

[14] R. I. McKinnon, Money and Capital in Economic Development, Brookings Institute, Washington, DC, USA, 1973.

[15] E. Shaw, Financial Deepening in Economic Development, Oxford University Press, 1973.

[16] A. Deaton, "Involuntary saving through unanticipated inflation," The American Economic Review, vol. 67, no. 5, pp. 899-910, 1977.

[17] R. J. Barro, "Are government bonds net worth?" Journal of Political Economy, vol. 82, no. 6, pp. 1095-1117, 1974.

[18] M. Rakshit, "On assessment and interpretation of savinginvestment estimates in India," Economic and Political Weekly, vol. 19, no. 2, pp. 753-776, 1983.

[19] J. A. Frankel and A. Razin, Fiscal Policies and the World Economy, The MIT Press, Cambridge, UK, 2nd edition, 1992.

[20] M. H. Pesaran, Y. Shin, and R. J. Smith, "Bounds testing approaches to the analysis of level relationships," Journal of Applied Econometrics, vol. 16, no. 3, pp. 289-326, 2001.

[21] P. K. Narayan, "The saving and investment nexus for China: evidence from cointegration tests," Applied Economics, vol. 37, no. 17, pp. 1979-1990, 2005. 

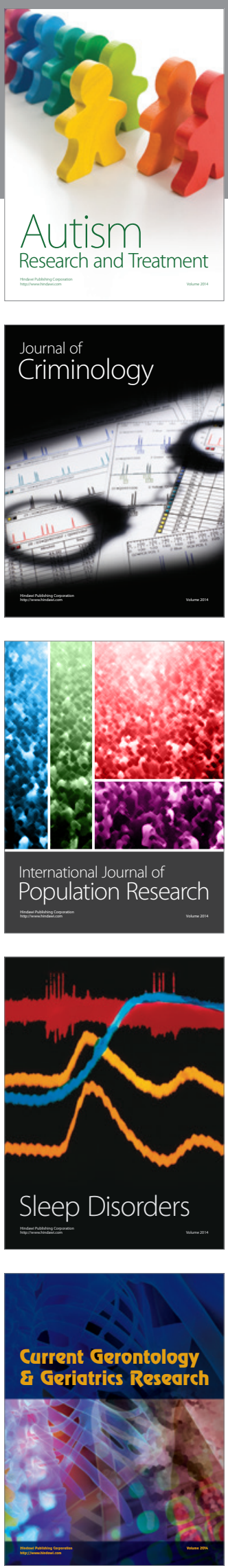
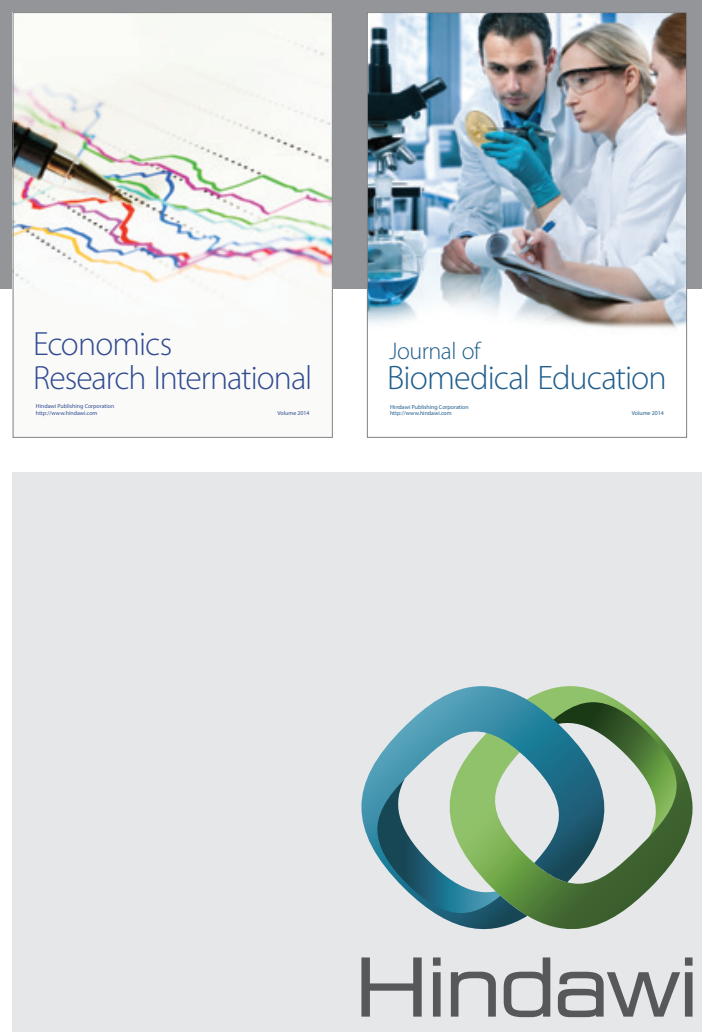

Submit your manuscripts at

http://www.hindawi.com
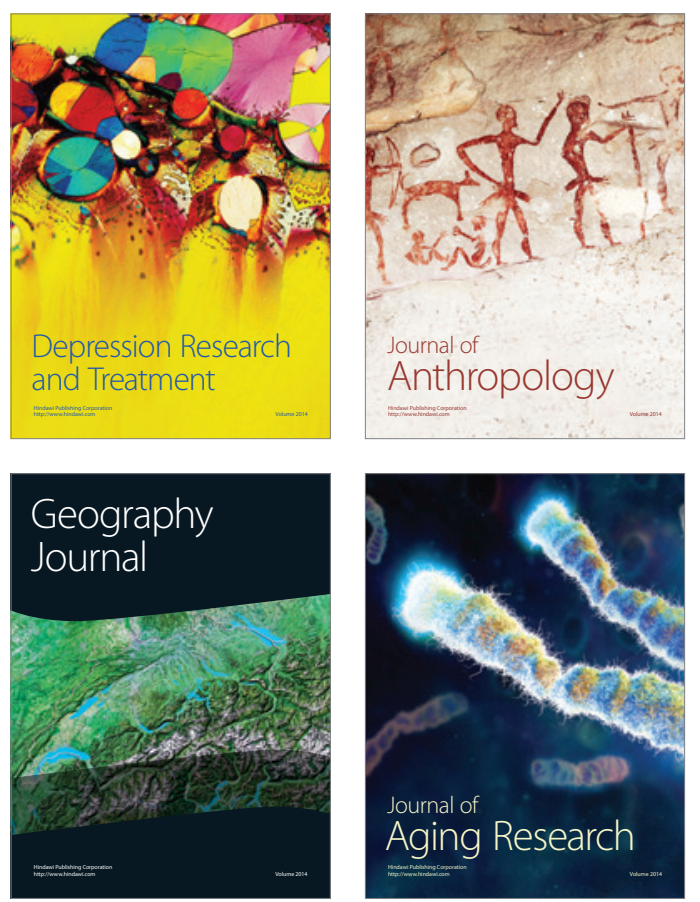
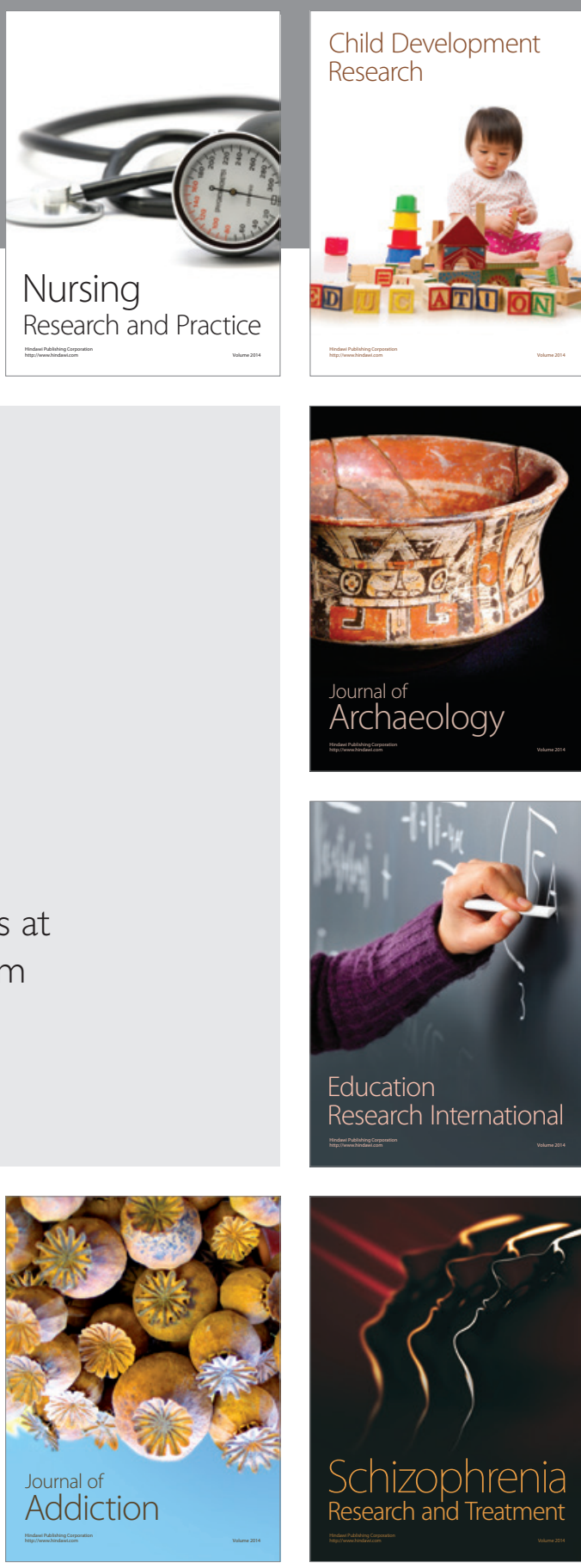

(D)
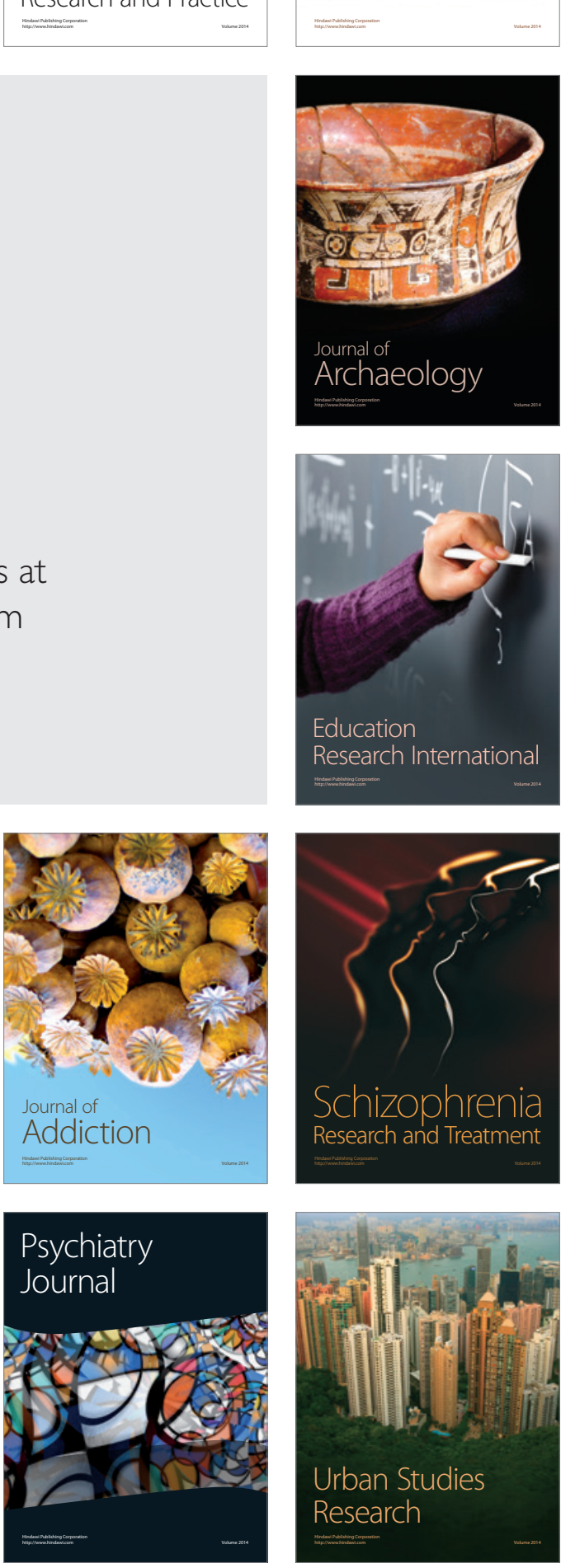